\title{
Design and Evaluation of Bible Learning Application using Elements of User Experience
}

\author{
Frederik Allotodang ${ }^{1}$, Herman Tolle ${ }^{2}$ \\ Computer Science Department \\ Brawijaya University, Malang, Indonesia
}

\author{
Nataniel Dengen ${ }^{3}$ \\ Computer Science Department \\ Mulawarman University, Samarinda, Indonesia
}

\begin{abstract}
Technological developments can encourage children to learn easily and help solve problems that often arise in the learning process. Sunday School students need learning media to make it easier to understand Christian Education. The method used in Sunday Schools still uses conventional methods which include face-to-face teaching and learning in class. This method often faces various challenges such as student's lack of focus. One of the solutions that are proposed in this paper is to design an Android-based learning application that will support the learning process. Application User Interface and User Experience (UI/UX) design will be built based on the Elements of User Experience methodology. The Elements of User Experience method will be used in the analysis and design process to maximize the usability and engagement level of the application. The learning materials will be designed based on Attention, Relevance, Confidence, and Satisfaction (ARCS) framework. ARCS will help the material design process to ensure the clarity and appropriateness of the material. The application will be implemented and tested on students to measure its effectiveness. The application trial has shown a promising improvement especially in student's engagement toward the materials.
\end{abstract}

Keywords-Christian education; Sunday school; element of user experience; ARCS; android application

\section{INTRODUCTION}

Christian Education nowadays is built on several objectives such as increasing student's religious knowledge and understanding of the Bible's contents and applying Christian values in their daily life [1]. Christian Education is implemented in many Christian churches through Sunday Schools. Sunday School is a Christian religious education activity intended for children aged 5-15 years and is usually held once a week every Sunday. Christian character is the concern of Christian parents in shaping the character of their children. The standard of Christian character to be achieved is a standard based on the Bible, not based on world philosophy [2]. Sunday school service is usually held in conjunction with the Public Service and is divided into several classes according to age ranges. The purpose of this class division is to adapt the material provided to suit the psychological age of each child. The teaching system in Sunday Schools also faces several problems. In modern and digital times, the teaching methods and media in many Sunday schools are considered to be lagging behind. Most students who are familiar with digital communication media such as cell phones and electronic tablets are more interested in accessing the internet and playing online games than in attending classes and activities in Sunday School. The teaching methods in most Sunday schools still use conventional methods. Teaching and learning activities include the teacher giving and presenting the material in front of the class. Teaching materials are given in written form on whiteboard in front of the class. As a result, many of the children did not pay attention to what the teacher gave because they were considered less attractive and the teachers also did not involve each child to contribute in the teaching and learning process. Sunday Schools are expected to be able to innovate so that the material taught becomes more interesting and relevant for children.

One of the innovations that want to be applied to overcome this problem is through designing a learning application for Sunday School using the Elements of User Experience methodology. The Elements of User Experience is a methodology used to develop a user interface and user experience (UI/UX) system which is divided into 5 stages, including Strategy, Scope, Structure, Skeleton, and Surface [3]. After the application is implemented, the next step is to measure the level of usability of the application and how effective it supports the learning process in Sunday Schools. This research is expected to provide solutions to overcome the problems faced in the learning process in most Sunday schools.

Several studies have been conducted in the application development process using the Elements of User Experience methodology. Most of the existing studies focus more on general-purpose applications and very few focus on educational applications especially for Christian Religious Education for Children. This research is expected to contribute in particular to combining application development methods with educational methods for children.

\section{Previous Study}

Several studies have been conducted based on the Elements of User Experience methodology. This method can be applied in web and mobile-based applications and several studies have tried to apply it. Ecelbarger, Hamlin, and McMcGrath have done this in the case of a web-based scheduling application [4]. Tong, Cui, and Chen have applied it to a more interactive mobile application like museum simulations [5]. Both studies have reported better results in terms of user experience. However, the application of this method is still very limited for educational-purpose applications. The biggest challenge in designing education-based applications is how to ensure that the applications made can increase the engagement of the learning process being carried out. Similar research was conducted by Nurul and Norasykin to develop a computer- 
programming learning application but it is more aimed at an adult audience with a simple and minimalistic user interface [6].

This research has its challenges because it has an audience of children aged 5-10 years who have a different application development approach to the adult audience. Several phases have to be modified to make a better approach to the problem. One of the main modifications is to combine the ARCS methodology at the phase of determining the application structure [7]. ARCS serves to ensure that the teaching materials provided are suitable for the intended learning abilities of the students.

\section{METHODOLOGY}

\section{A. Elements of User Experience}

The Elements of User Experience consists of five stages and starts from the lowest stage, Strategy stage. This stage is used to collect data related to system development that will be carried out to get product objectives and user needs. This stage determines the purpose of the application being made and the specific needs of Sunday School children in order to be able to design an appropriate system and suitable to user needs.

The second stage, Scope stage aims to determine the scope of the system you want to build and clearly define the system requirements. The strategy to be used is to design system requirements in accordance with the results of the questionnaire that was implemented in the previous stage.

The Structure stage contains a systematic design for how the system will run and how the system responds to users. The method used to describe interactions with users is to use a usecase diagram to explain in detail how users interact with the system being built, and for the information storage process, ER Diagram is used as an explanation of how the information will be stored.

The Skeleton stage is the stage for designing a system prototype to provide an overview of how the system works. The method will use mockups to explain how the existing display in the application will be developed.

The Surface stage is the final stage for designing the final result of the application being built. The entire process can be seen in Fig. 1.

\section{B. Design Process}

The stage of making the application structure provides functional description of how the system works. The functional description of the system is manifested in the form of a simple interface design of an application mockup. Mockups are structured models or replicas that describe the appearance of the application and the flow of application functions. An example of the application mockup can be seen in Fig. 2.

\section{Implementation Process}

At the implementation stage, mockups that were developed in the previous stage will begin to be built using the selected technology, React Native and MySQL database. React Native is a framework that allows mobile application development using the JavaScript programming language [8].

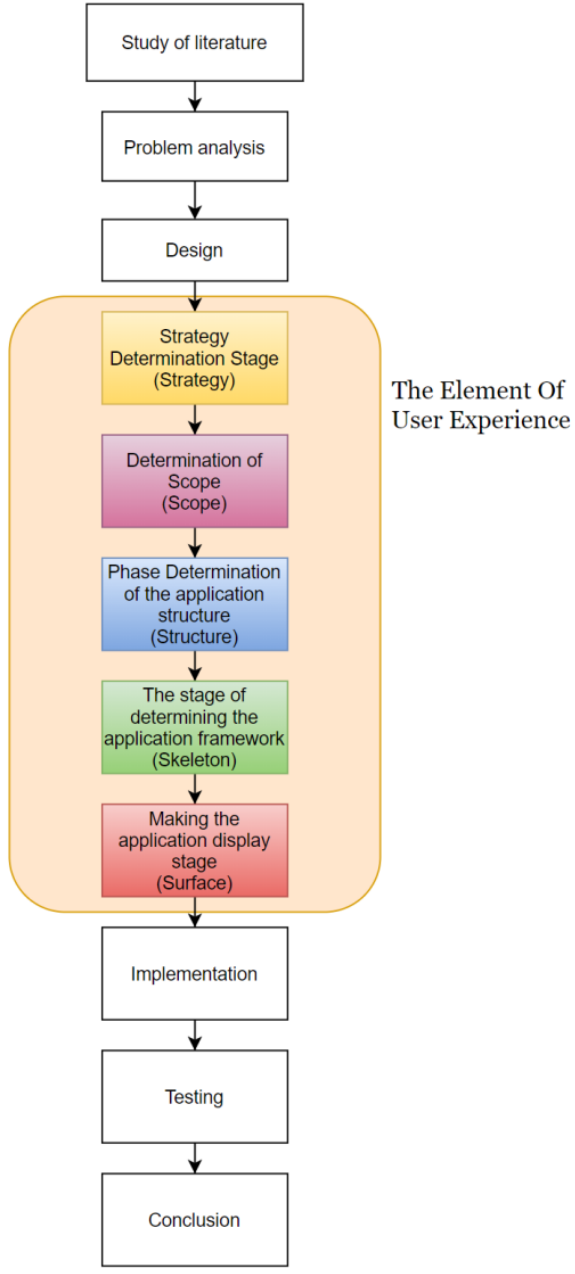

Fig. 1. Research Methodology.

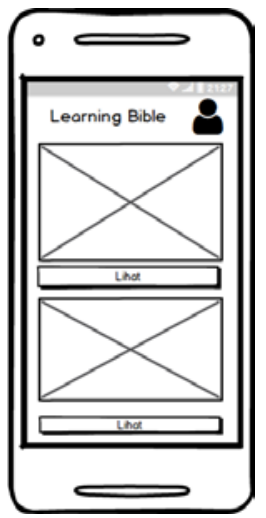

Fig. 2. Application Mockup.

User interface implementation is the final stage of The Elements of User Experience methodology. The mockup created in the previous process will be manifested as a user interface and becomes the blueprint of the actual application display development process. The existing application is designed to be as simple and attractive as possible, with relatively bright colors, considering the relatively young age range of users. An example of a user interface that has been developed can be seen in Fig. 3. 


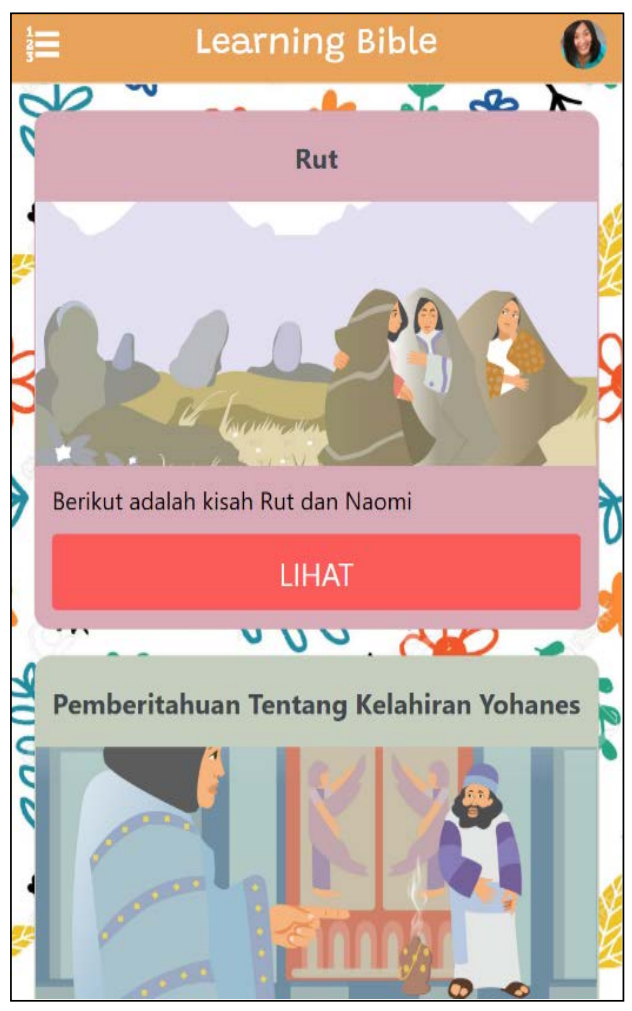

Fig. 3. Application user Interface.

\section{Testing Process}

This test was carried out at the Toraja Church in Samarinda, East Kalimantan. Tests will be carried out on students of the Toraja Church Sunday School who are in the age range of 5-10 years. Sunday School students will also be accompanied by teachers during the testing process. The method used in testing is the System Usability Scale (SUS) [9].

SUS is a method of testing the usability of an application containing 10 questions with an assessment range between 1 and 5 [10]. The SUS list of questions contains questions to determine whether the application is easy enough to use by its designated users, especially children. A list of SUS questions can be seen in Table I.

TABLE I. SUS QUESTIONS

\begin{tabular}{|c|c|}
\hline No & Questions \\
\hline 1 & I think I will use this application often \\
\hline 2 & I think this application is too complicated but can be simplified \\
\hline 3 & I think this application is easy to use \\
\hline 4 & $\begin{array}{l}\text { I think I need help from a technical person to be able to use this } \\
\text { application }\end{array}$ \\
\hline 5 & $\begin{array}{l}\text { I found that there are various features that are well integrated in this } \\
\text { application }\end{array}$ \\
\hline 7 & I think there are many things that are inconsistent with this application \\
\hline 8 & $\begin{array}{l}\text { I think the majority of users will be able to learn this application } \\
\text { quickly }\end{array}$ \\
\hline 9 & I find this application very impractical to use \\
\hline 10 & I really believe that I can use this application \\
\hline
\end{tabular}

After the user has filled in, the method for calculating the SUS score is as follows:

- For each odd question, the score given by the user must be reduced by 1 (formula: X-1).

- For each even question, subtract the value given by the user from 5 (formula: 5-X).

- The value obtained from each question is then added and multiplied by 2.5 .

- The result is a SUS score and should be in the 0-100 range General guidelines on the interpretation of SUS scores can be seen in Table II.

TABLE II. SUS GUIDELINES

\begin{tabular}{|l|l|l|}
\hline SUS Score & Grade & Predicate \\
\hline$>80,3$ & A & Excellent \\
\hline $68-80,3$ & B & Good \\
\hline 68 & C & Okay \\
\hline $51-68$ & D & Poor \\
\hline$<51$ & E & Awful \\
\hline
\end{tabular}

\section{RESUltS AND DISCUSSION}

After the application design process, the application was tested on 24 user respondents. The trial was carried out for 30 minutes for each respondent where 20-25 minutes was the application trial stage and 5-10 minutes was used to fill out the questionnaire. The questionnaire was designed based on the System Usability Scale (SUS) method which has 10 questions. Each respondent was also accompanied by a Sunday School teacher to assist in the testing process and filling out the questionnaire. The results of the application trial can be seen in Table III.

TABLE III. SUS GUIDELINES

\begin{tabular}{|l|l|l|l|l|l|}
\hline \multirow{2}{*}{ QUESTIONS } & \multicolumn{5}{|l|}{ Score Given by User } \\
\cline { 2 - 9 } & $\mathbf{1}$ & $\mathbf{2}$ & $\mathbf{3}$ & $\mathbf{4}$ & $\mathbf{5}$ \\
\hline I think I will use this application often & 1 & 1 & 2 & 16 & 4 \\
\hline $\begin{array}{l}\text { I think this application is too complicated but } \\
\text { can be simplified }\end{array}$ & 2 & 16 & 3 & 2 & 1 \\
\hline I think this application is easy to use & 0 & 4 & 1 & 17 & 2 \\
\hline $\begin{array}{l}\text { I think I need help from a technical person to } \\
\text { be able to use this application }\end{array}$ & 3 & 15 & 5 & 1 & 0 \\
\hline $\begin{array}{l}\text { I found that there are various features that are } \\
\text { well integrated in this application }\end{array}$ & 0 & 1 & 1 & 16 & 6 \\
\hline $\begin{array}{l}\text { I think there are many things that are } \\
\text { inconsistent with this application }\end{array}$ & 2 & 16 & 6 & 0 & 0 \\
\hline $\begin{array}{l}\text { I think the majority of users will be able to } \\
\text { learn this application quickly }\end{array}$ & 0 & 1 & 2 & 16 & 5 \\
\hline I find this application very impractical to use & 4 & 17 & 2 & 1 & 0 \\
\hline I really believe that I can use this application & 0 & 2 & 2 & 16 & 4 \\
\hline $\begin{array}{l}\text { I have to learn many things first before I can } \\
\text { use this application }\end{array}$ & 3 & 17 & 2 & 2 & 0 \\
\hline
\end{tabular}


The trial results were then calculated to obtain a score for each question. For odd questions, the formula used is $\mathrm{X}-1$ where $\mathrm{X}$ is the score given by the user. The sum is then divided by 24 (according to the number of respondents). On the other hand, for even questions, the formula used is $5-\mathrm{X}$. The sum is then divided by 24. The SUS Calculation Results can be seen in Table IV.

TABLE IV. SUS CALCULATION RESULTS

\begin{tabular}{|l|l|l|l|l|l|l|}
\hline \multirow{2}{*}{ Questions } & \multicolumn{5}{|l|}{ SUS Calculations } & \multirow{2}{*}{ Score } \\
\cline { 2 - 7 } & $\mathbf{1}$ & $\mathbf{2}$ & $\mathbf{3}$ & $\mathbf{4}$ & $\mathbf{5}$ & \\
\hline I think I will use this application often & 0 & 1 & 4 & 48 & 16 & 2,88 \\
\hline $\begin{array}{l}\text { I think this application is too } \\
\text { complicated but can be simplified }\end{array}$ & 8 & 48 & 6 & 2 & 0 & 2,67 \\
\hline I think this application is easy to use & 0 & 4 & 2 & 51 & 8 & 2,71 \\
\hline $\begin{array}{l}\text { I think I need help from a technical } \\
\text { person to be able to use this application }\end{array}$ & 12 & 45 & 10 & 1 & 0 & 2,83 \\
\hline $\begin{array}{l}\text { I found that there are various features } \\
\text { that are well integrated in this } \\
\text { application }\end{array}$ & 0 & 1 & 2 & 48 & 24 & 3,13 \\
\hline $\begin{array}{l}\text { I think there are many things that are } \\
\text { inconsistent with this application }\end{array}$ & 8 & 48 & 12 & 0 & 0 & 2,83 \\
\hline $\begin{array}{l}\text { I think the majority of users will be } \\
\text { able to learn this application quickly }\end{array}$ & 0 & 1 & 4 & 48 & 20 & 3,04 \\
\hline $\begin{array}{l}\text { I find this application very impractical } \\
\text { to use }\end{array}$ & 16 & 51 & 4 & 1 & 0 & 3,00 \\
\hline $\begin{array}{l}\text { I really believe that I can use this } \\
\text { application }\end{array}$ & 0 & 2 & 4 & 48 & 16 & 2,92 \\
\hline $\begin{array}{l}\text { I have to learn many things first before } \\
\text { I can use this application }\end{array}$ & 12 & 51 & 4 & 2 & 0 & 2,88 \\
\hline Final SUS Score (Total score x 2.5) & & & & 72,19 \\
\hline
\end{tabular}

The score obtained from each question is then added and multiplied by the constant 2.5 and the final SUS score is 72.19. The score based on Table II shows an outcome with a good predicate. A good SUS score indicates an increase in the ease of the learning process.

\section{CONCLUSION}

The Elements of User Experience allows the development of an Android-based application that suits the needs of users, especially students in the age range of 5 to 10 years old. The testing result using the System Usability Scale (SUS) method produces a final value of 72.19. Based on the SUS score guidelines, the score shows a good result that indicates an increase in the ease of the learning process.

These results also show that the Element of User Experience method can be applied to the development of mobile-based applications for educational purposes. This method will increase the usability of the application which is a major factor for its designated users.

Further research can be carried out using the same method but in different cases and age ranges. This study is focused on target users with an age range between 5-10 years old. Research at different age ranges will provide useful information on how effective this method is at younger or older ages.

\section{REFERENCES}

[1] Busthan Abdy (2019). Pendidikan Agama Kristen (PAK) dan Etika Kristen. Kupang: Yayasan Kasih Imanuel Mahawira.

[2] Hartono. Handreas. (2014). Membentuk Karakter Kristen Pada Anak Keluarga Kristen. Jurnal Kurios: Jurnal Teologi Dan Pendidikan Agama Kristen, Vol. 2, No. 1, s.

[3] Garrett, Jesse James. (2011) The Elements of User Experience: UserCentered Design for the Web and Beyond, Second Edition, California: New Riders.

[4] A.N Ecelbarger, P.D. Hamlin, S.C McGrath. Dkk. (2020) User Experience Design to Synchronize Government Acquisition Strategy and Schedule.

[5] Yanting Tong, Binyue Cui, and Yulin Chen. (2018) Research on UI Visual Design of Intangible Cultural Heritage Digital Museum Based on User Experience.

[6] Nurul F,Z \& Norasykin M,Z (2018) Code Puzzle: ActionScript 2.0 Learning Application Based on Problem Based Learning Approach University Teknology Malaysia.

[7] Pratama, A. (2015). Pengembangan Multimedia Pembelajaran Berbasis Educational Games dnegan Menggunakan Strategi Pembelajaran ARCS.

[8] Xingwei Zhou, Wenshan Hu, and Guo-Ping Liu. (2020) React-Native Based Mobile App for Online Experimentation.

[9] Brooke, J. 1996 . SUS - A Quick and Dirty Usability Scale. United Kingdom: Redhatch.

[10] Rasmilla (2018). Evaluasi Website Dengan Menggunakan System Usability Scale (SUS) Pada Perguruan Tinggi Swasta di Palembang Volume 4, Hal. 89 - 98. 